\title{
Research of the Contextual Interference and Augmented Feedback on Golf Putting Skills
}

\author{
Lifei Han ${ }^{\mathrm{a}}$, Wei Song ${ }^{\mathrm{c}}$, \\ Guojie Zhang \\ Social P.E. Dept., He Bei Institute \\ OF P.E. \\ Shijiazhuang, China \\ a 446930112@qq.com; '357488842@qq.com \\ d460518344@qq.com
}

\begin{abstract}
This research is to discuss the effect of contextual interference and augmented feedback applied in improving golf putter skills by using literature materials, experimental research method, comparative research method and mathematical statistic, etc. It adopts the practice methods and feedback ways adapted by students to improve the golf performance. This text is to promote the practice methods and feedback ways derived from the contextual interference during golf teaching. The practice methods should strengthen the exercise frequency and two augmented feedback ways should be more obvious to distinguish between degrees during golf teaching.
\end{abstract}

Keywords- augmented feedback; Golf; contextual interference

\section{INTRODUCTION}

The empirical part of golf putting skills performance in this research uses experimental interaction method by applying the two factors to obtain experimental data which is analysed and processed through statistics.

\section{SUBJECTS AND METHODS OF RESEARCH}

\section{A. Subjects}

The participants of this research are 60 students who have not been given the golf putter learning in Hebei Physical Education Institutes, 2010 Grade. They are randomly divided into four experimental groups and each of them is 15 people to learn and practice golf putter, including long-distance and short-distance push batting. Discuss different practice methods of contextual interference (random practice and concentrated practice) and different augmented feedbacks (acknowledgement of results and performance of skills), explore the influence of students who have not been given the golf putter learning to confirm the best practice method and feedback way, and make an effective combination of them.

\section{B. Methods of research}

1) Literature materials

2) Expert-interview method

3) Experimental research method

\author{
Jing Rong \\ Foreign Language Dept., He Bei Institute \\ of P.E. \\ Shijiazhuang, China \\ b736821030@qq.com
}

The empirical part of golf putter skills performance in this research uses experimental interaction method by applying the two factors to obtain experimental data which is analysed and processed through statistics.

\section{The definitions}

1) Contextual interference. Contextual interference was discovered by Batting (1966) from a series of words learning researches. In each practice, learning a variety of similar skills at the same time, that is, the "random practice group" can lead to a higher interference phenomenon; practicing only one skill as "collective group" can lead to a lower interference phenomenon.

2) Augmented feedback. The external feedback: It is the information offered by non-learner to make learners understand itself action feedback. Gentile(1972) first divided it into knowledge of result as KR and knowledge of performance as KP.

\section{RESULTS AND ANALYSIS}

\section{A Golf putt acquisition period}

1) Score of putt accuracy

a) Score of long putt accuracy

\begin{tabular}{lcccccc}
\hline $\begin{array}{l}\text { Source of } \\
\text { variation }\end{array}$ & $\begin{array}{l}\text { The sum of } \\
\text { squared } \\
\text { residuals }\end{array}$ & $\begin{array}{c}\text { Degrees of } \\
\text { freedom }\end{array}$ & $\begin{array}{c}\text { Mean } \\
\text { square }\end{array}$ & F & P-value \\
test & & \\
\hline $\begin{array}{l}\text { Group1 (high } \\
\text { and low }\end{array}$ & 4.534 & 1 & 4.37 & 4.30 & 0.043 \\
background) & & & & & & \\
$\begin{array}{l}\text { Group2 (The } \\
\text { results of skills }\end{array}$ & 6.53 & 1 & 6.53 & 6.42 & 0.014 \\
$\begin{array}{l}\text { performance) } \\
\text { Group1 } \times \text { Group2 } \\
\text { Error }\end{array}$ & 1.35 & 1 & 1.35 & 1.32 & 0.254 \\
Total & 56.928 & 56 & 1.01 & & & \\
& 816.84 & 60 & & & &
\end{tabular}

Figure 1. Golf LONG PutT Hit ACCURACY IN TWO-FACTOR ANALYSIS OF VARIANCE TABLE

The result shows: the contextual interference and augmented feedback interaction is not significant on the accuracy of long-range interaction. $(\mathrm{F}=1.32, \mathrm{P}=1.32>$ 
0.05) Main effect in the different background groups is striking significant. $\quad(\mathrm{F}=4.30 ; \mathrm{P}=0.043<0.05)$ Accuracy of long distance shot is caused by pushing and hitting the ball smoothly, continuously and swinging steadily and other

\begin{tabular}{llllcc}
\hline Source & The sum & Degrees & Mean & F & P- \\
of & of squared & of & square & test & value \\
Variation & residuals & freedom & & & \\
\hline
\end{tabular}

\begin{tabular}{lccccc}
$\begin{array}{l}\text { Group1 (high } \\
\text { and low }\end{array}$ & 0.096 & 1 & 0.096 & 0.164 & 0.687 \\
background) & & & & & \\
Group2 (The & & & & & \\
results of skills & 0.216 & 1 & 0.216 & 0.370 & 0.545 \\
performance) & & & & & \\
Group1×Group2 & 0.39 & 1 & 0.384 & 0.658 & 0.421 \\
Error & 32.69 & 56 & 0.584 & & \\
& Total & & 2093.76 & 60 & \\
\hline
\end{tabular}

FiguRE 2 GOLF SHORT PUTT HIT ACCURACY IN TWO-FACTOR ANALYSIS OF VARIANCE TABLE

The result shows: the contextual interference and augmented feedback interaction is not significant on the accuracy of short-range interaction $(\mathrm{F}=0.658 ; \mathrm{P}=0.421>0.05)$, Main effect in the different background groups is not significant $(\mathrm{F}=0.164 ; \mathrm{P}=0.687>0.05)$.

Hitting the target is easy to be judged and controlled because of the small range of motion. Besides, it can also develop the feeling of hitting the ball. The action of short putter is easy to be mastered and the routine is easy to be certain, intensity can be better controlled and pole amplitude on the strength of the control is easy to affect the accuracy of push hit.

\section{2) Standard score of push action}

a) Standard score of long-distance strike action

\begin{tabular}{|c|c|c|c|c|c|}
\hline $\begin{array}{l}\text { Source } \\
\text { of } \\
\text { Variation }\end{array}$ & $\begin{array}{l}\text { The sum } \\
\text { of squared } \\
\text { residuals }\end{array}$ & $\begin{array}{l}\text { Degrees } \\
\text { of } \\
\text { freedom }\end{array}$ & $\begin{array}{l}\text { Mean } \\
\text { square }\end{array}$ & $\begin{array}{l}\mathrm{F} \\
\text { test }\end{array}$ & $\begin{array}{l}\text { P- } \\
\text { value }\end{array}$ \\
\hline $\begin{array}{l}\text { Group1 (high } \\
\text { and low } \\
\text { background) }\end{array}$ & 0.081 & 1 & 0.081 & 0.188 & 0.666 \\
\hline $\begin{array}{l}\text { Group2 (The } \\
\text { results of skills } \\
\text { performance) }\end{array}$ & 2.166 & 1 & 2.166 & 5.048 & 0.029 \\
\hline Group1×Group2 & 0.193 & 1 & 0.193 & 0.449 & 0.506 \\
\hline Error & 24.027 & 56 & 0.429 & & \\
\hline & Total & \multicolumn{2}{|c|}{906.466} & \multicolumn{2}{|l|}{60} \\
\hline
\end{tabular}

FIGURE3 ANALYSIS OF TWO-FACTOR VARIANCE IN GOLF LONG-PUTT ACTION STANDARD

The result shows: the contextual interference and augmented feedback interaction is not significant on the standard score of long-putt action $(\mathrm{F}=0.449 ; \mathrm{P}=0.506>0.05)$;
Main effect in the different background groups is not significant $(\mathrm{F}=0.188 ; \mathrm{P}=0.666>0.05$ )

b) Standard score of short-distance strike action

\begin{tabular}{|c|c|c|c|c|c|}
\hline $\begin{array}{l}\text { Source } \\
\text { of } \\
\text { Variation }\end{array}$ & $\begin{array}{l}\text { The sum } \\
\text { of squared } \\
\text { residuals }\end{array}$ & $\begin{array}{l}\text { Degrees } \\
\text { of } \\
\text { freedom }\end{array}$ & $\begin{array}{l}\text { Mean } \\
\text { square }\end{array}$ & $\begin{array}{c}\mathrm{F} \\
\text { test }\end{array}$ & $\begin{array}{c}\text { P- } \\
\text { value }\end{array}$ \\
\hline $\begin{array}{l}\text { Group1 (high } \\
\text { and low } \\
\text { background) }\end{array}$ & 0.011 & 1 & 0.011 & 0.032 & 0.859 \\
\hline $\begin{array}{l}\text { Group2 (The } \\
\text { results of skills } \\
\text { performance) }\end{array}$ & 0.067 & 1 & 0.067 & 0.198 & 0.658 \\
\hline Group1×Group2 & 0.171 & 1 & 0.171 & 0.507 & 0.480 \\
\hline Error & 18.869 & 56 & 0.337 & & \\
\hline & Total & \multicolumn{2}{|c|}{919.280} & 60 & \\
\hline
\end{tabular}

FIGURE4 ANALYSIS OF TWO-FACTOR VARIANCE IN GOLF SHORT-PUTT ACTION STANDARD

The result shows: the contextual interference and augmented feedback interaction is not significant on the standard score of short-putt action $(\mathrm{F}=0.819 ; \mathrm{P}=0.369>0.05)$; Main effect in the different background groups is not significant $(\mathrm{F}=0.131 ; \mathrm{P}=0.719>0.05)$.

The quality of high putter action needs the ability of ball-control and a benign psychological quality which can make the ball scroll according to the ideal trajectory.

\section{$B$ Golf putt reserved stage}

\section{1) Score of putt accuracy}

a) Score of long-distance strike accuracy

\begin{tabular}{llllcr}
\hline Source & The sum & Degrees & Mean & F & P- \\
of & of squared & of & square & test & value \\
Variation & residuals & freedom & & & \\
\hline
\end{tabular}

Group1 (high

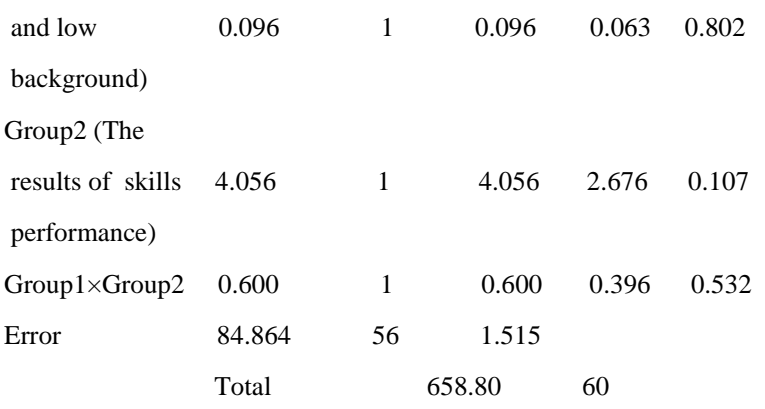

FIGURE5 ANALYSIS OF TWO-FACTOR VARIANCE IN THE ACCURACY OF GOLF LONG-PUTT

The result shows: the contextual interference and augmented feedback interaction is not significant on the accuracy of long-putt action $(\mathrm{F}=0.396 ; \mathrm{P}=0.532>0.05)$; Main effect in the different background groups is not significant $\mathrm{F}=0.063 ; \mathrm{P}=0.802>0.05$ ). 
b)Score of short-distance strike accuracy]

\begin{tabular}{|c|c|c|c|c|c|}
\hline $\begin{array}{l}\text { Source } \\
\text { of } \\
\text { Variation }\end{array}$ & $\begin{array}{l}\text { The sum } \\
\text { of squared } \\
\text { residuals }\end{array}$ & $\begin{array}{l}\text { Degrees } \\
\text { of } \\
\text { freedom }\end{array}$ & $\begin{array}{l}\text { Mean } \\
\text { square }\end{array}$ & $\begin{array}{c}F \\
\text { test }\end{array}$ & $\begin{array}{c}\text { P- } \\
\text { value }\end{array}$ \\
\hline $\begin{array}{l}\text { Group1 (high } \\
\text { and low } \\
\text { background) }\end{array}$ & 0.075 & 1 & 0.075 & 0.051 & 0.823 \\
\hline $\begin{array}{l}\text { Group2 (The } \\
\text { results of skills } \\
\text { performance) }\end{array}$ & 0.489 & 1 & 0.489 & 0.330 & 0.568 \\
\hline Group1×Group2 & 0.036 & 1 & 0.036 & 0.025 & 0.876 \\
\hline \multirow[t]{2}{*}{ Error } & 82.989 & 56 & 1.482 & & \\
\hline & Total & \multicolumn{2}{|c|}{1878.840} & 60 & \\
\hline
\end{tabular}

FIGURE6 ANALYSIS OF TWO-FACTOR VARIANCE IN THE ACCURACY OF GOLF SHORT-PUTT

The result shows: the contextual interference and augmented feedback interaction is not significant on the accuracy of short-putt action $(\mathrm{F}=0.025 ; \mathrm{P}=0.876>0.05)$; Main effect in the different background groups is not significant （ $\mathrm{F}=0.051 ; \mathrm{P}=0.823>0.05$ ).

According to the result of the accuracy of long-distance putt and standard of action, Bernstein said "Practice is an unrepeated repeated specific type.” During acquisition period, participants have understood and processed the action skills, and joined more activities to solve problems. High contextual interference needs high-strength attention to allow the differences among actions become more clearly in your brain. Because there is no obvious distress in high contextual interference during acquisition period, the only change is in the distance. During reservation period, the score of accuracy in high contextual interference groups is still better than low ones.

According to Schmidt's theory, participants perform an action through memory, make a response to that action, control and revise the action, which is the real performance of learning in this stage. During reservation period, participants have shaped a good feeling of muscle and become memory during acquisition period; at the same time, they have certain successful experience in putt. It can get a fine test result during reservation period.

2)Standard score of putt action

a) Standard score of long-putt

\begin{tabular}{|c|c|c|c|c|}
\hline & & $\begin{array}{l}\text { High } \\
\text { background } \\
\text { interference }\end{array}$ & $\begin{array}{l}\text { Low } \\
\text { background } \\
\text { interference }\end{array}$ & $\begin{array}{l}\text { Group } \\
\text { averages }\end{array}$ \\
\hline $\begin{array}{l}\text { Skills } \\
\text { results' } \\
\text { findings }\end{array}$ & $\begin{array}{l}\text { Averages } \\
\text { Standard } \\
\text { deviations }\end{array}$ & $\begin{array}{l}3.45 \\
0.41\end{array}$ & $\begin{array}{c}3.40 \\
0.54\end{array}$ & $\begin{array}{l}3.43 \\
0.47\end{array}$ \\
\hline $\begin{array}{l}\text { Skills } \\
\text { Performances, } \\
\text { findings }\end{array}$ & $\begin{array}{l}\text { Averages } \\
\text { Standard } \\
\text { deviations }\end{array}$ & $\begin{array}{l}3.63 \\
0.55\end{array}$ & $\begin{array}{l}3.61 \\
0.67\end{array}$ & $\begin{array}{l}3.63 \\
0.59\end{array}$ \\
\hline $\begin{array}{l}\text { Group } \\
\text { averages } \\
\text { deviation }\end{array}$ & $\begin{array}{l}\text { Averages } \\
\text { Standard }\end{array}$ & $\begin{array}{l}3.54 \\
0.54\end{array}$ & $\begin{array}{l}3.51 \\
0.55\end{array}$ & $\begin{array}{l}3.53 \\
0.54\end{array}$ \\
\hline
\end{tabular}

FigURE7 AVERAGES AND STANDARD DEVIATIONS OF GOLF LONG-PUTT ACTION STANDARD

\begin{tabular}{lccccc}
\hline $\begin{array}{l}\text { Source } \\
\text { of }\end{array}$ & $\begin{array}{c}\text { The sum } \\
\text { of squared } \\
\text { residuals }\end{array}$ & $\begin{array}{c}\text { Degrees } \\
\text { of } \\
\text { freedom }\end{array}$ & $\begin{array}{c}\text { Mean } \\
\text { square }\end{array}$ & $\begin{array}{l}\text { F } \\
\text { test }\end{array}$ & $\begin{array}{c}\text { P- } \\
\text { value }\end{array}$ \\
\hline $\begin{array}{l}\text { Group1 (high } \\
\text { and low }\end{array}$ & 0.024 & 1 & 0.024 & 0.082 & 0.776 \\
$\begin{array}{l}\text { background) } \\
\text { Group2 (The } \\
\text { results of skills } \\
\text { performance) }\end{array}$ & 0.600 & 1 & 0.600 & 2.038 & 0.159 \\
$\begin{array}{l}\text { Group1×Group2 } \\
\text { Error }\end{array}$ & 0.003 & 1 & 0.003 & 0.009 & 0.925 \\
& 16.491 & 56 & 0.294 & & \\
\hline
\end{tabular}

Figure8 ANALYSIS OF TWO-FACTOR VARIANCE IN GOLF LONG-PUTT ACTION STANDARD

The result shows: the contextual interference and augmented feedback interaction is not significant on the standard score of long-putt action( $\mathrm{F}=2.038 ; \mathrm{P}=0.159>0.05)$; Main effect in the different background groups is not significant ( $\mathrm{F}=0.009 ; \mathrm{P}=0.925>0.05$ ) ; Main effect in the different skills learned groups is not significant （ $\mathrm{F}=0.082 ; \mathrm{P}=0.776>0.05 ）$.

b) Standard score of short-putt

\begin{tabular}{|c|c|c|c|c|c|}
\hline $\begin{array}{l}\text { Source } \\
\text { of } \\
\text { Variation }\end{array}$ & $\begin{array}{l}\text { The sum } \\
\text { of squared } \\
\text { residuals }\end{array}$ & $\begin{array}{l}\text { Degrees } \\
\text { of } \\
\text { freedom }\end{array}$ & $\begin{array}{l}\text { Mean } \\
\text { square }\end{array}$ & $\begin{array}{c}\mathrm{F} \\
\text { test }\end{array}$ & $\begin{array}{c}\text { P- } \\
\text { value }\end{array}$ \\
\hline $\begin{array}{l}\text { Group1 (high } \\
\text { and low } \\
\text { background) }\end{array}$ & 0.193 & 1 & 0.192 & 0.906 & 0.345 \\
\hline $\begin{array}{l}\text { Group2 (The } \\
\text { results of skills } \\
\text { performance) }\end{array}$ & 0.054 & 1 & 0.054 & 0.254 & 0.616 \\
\hline Group1×Group2 & 0.017 & 1 & 0.017 & 0.078 & 0.781 \\
\hline Error & 11.904 & 56 & 0.213 & & \\
\hline & Total & \multicolumn{2}{|c|}{779.720} & 60 & \\
\hline
\end{tabular}

FigURE 9 ANALYSIS OF TWO-FACTOR VARIANCE IN GOLF SHORT PUTT ACTION STANDARD

The result shows: the contextual interference and augmented feedback interaction is not significant on the standard score of short-putt action( $\mathrm{F}=0.078 ; \mathrm{P}=0.781>0.05)$; Main effect in the different background groups is not significant $(\mathrm{F}=0.906 ; \mathrm{P}=0.345>0.05)$; Main effect in the different skills learned groups is not significant $(\mathrm{F}=0.254 ; \mathrm{P}=0.616>0.05)$. According to the accuracy and standard score of putt action, we know in such as short distance putt of relatively simple action, it can promote the study in every learning strategy. The accuracy of short-putt is easy to improve, hit-distance is easy to judge and amplitude is easy to control. It can keep the accuracy of short-putt if you have a good psychological quality.

\section{CONCLUSION AND SUGGESTIONS}

\section{A Conclusion}

1) Methods of practice and feedback derived from contextual interference and augmented feedback enrich the golf teaching mode and method and show a certain degree of teaching effect advantage. 
2) Golf putt technology teaching training derived from the random practice way of contextual interference has a stronger stimulation on students' interest in learning.

\section{B Suggestions}

1) The golf teaching should promote the practice ways from contextual interference and two feedback ways of augmented feedback.

2) During golf teaching and training, teachers should give different feedback ways to students according to characteristics of putt and the actual situation. Moreover, the two degrees of differentiation should be more obvious.

3) During golf teaching and training, it is better to strengthen the research of contextual interference, explicit the relationship between features of golf and the augmented feedback.

\section{REFERENCES}

[1] Richard A.Magill 【U.S.】 Zhang Zhongqiu et al. The motor skill learning and control of China light industry press $[\mathrm{M}]$ in January 2006

[2] Liu xiaoru Feng Yan . Closed loop control of motor skill learning and control mode [J]. Journal of shenyang sports college in June 2005, 24 (3)

[3] Yu Zihui Different background interference on the lele ball performance of lower grade schoolchildren in elementary school lower grade schoolchildren [D] Master thesis in January 2009 education class of Taidong university institute in the republic of China

[4] Li Hongen Contextual interference and feedback performance influence on shooting skill learning [D] Master thesis in December 2004, education class of Taidong university institute in the republic of China

[5] Li Hongyu, He Yili Psychology of learning ability development [M]. Hefei: anhui education press, 2004-6 